\title{
FUTURISTISCHE GELUIDEN: VLOEKENDE KLEUREN + CHROMATISCHE AKKOORDEN + LAWAAIKUNST + ZANG TUMB TUMB + GEFILMDE ANALOGIEËN
}

Futurisme = lawaai ?

'Het leven in de oudheid was volledige stilte', verklaarde in I9I3 Luigi Russolo, 'maar in de negentiende eeuw is dankzij de uitvinding van de machine het lawaai geboren. Dit triomfeert nu en heerst over de gewaarwordingen van de mens. ${ }^{\text {I }}$ Negentig jaar geleden belichaamde een dergelijke uitspraak het typisch Futuristische credo. Volgens de dialectische moderniteitstheorie ${ }^{2}$ kan men stellen dat het Futurisme, als eerste historische avant-garde beweging, zich duidelijk liet inspireren door het tumultueuze moderne stadsleven, dat op zijn beurt putte uit het Futurisme: het leven werd steeds Futuristischer, steeds dynamischer, steeds lawaaieriger. Maar waaruit bestond dit lawaai? Waar kwam het vandaan en hoe werd het door de Futuristische kunstenaars genoteerd? De parodistische partituur Oublions le Futur, veux-tu... (I9I3) (afb. I) spreekt tot de verbeelding: deze compositie voor een 'trage' (dus passéïstische, anti-Futuristische) wals, die door de anonieme karikaturist aan Filippo Tommaso Marinetti, de stichter van het Futurisme, wordt toegeschreven, lijkt oorverdovend door de combinatie van allerlei geluiden, gegrepen uit zowel het landelijke als het stedelijke leven. In het begin van de jaren tien van de twintigste eeuw werden in Europese cultuurbladen vaak karikaturale illustraties van de Futuristische kunst opgenomen, waardoor een stereotype beeld van deze nieuwe 'trend' werd geschapen. Zo stelde men de schilderkunst van de Italiaanse avant-garde voor als een kinderlijke vorm van de chronofotografie, ${ }^{3}$ terwijl haar muziekkunst niet anders dan pure kakofonie zou zijn geweest. 


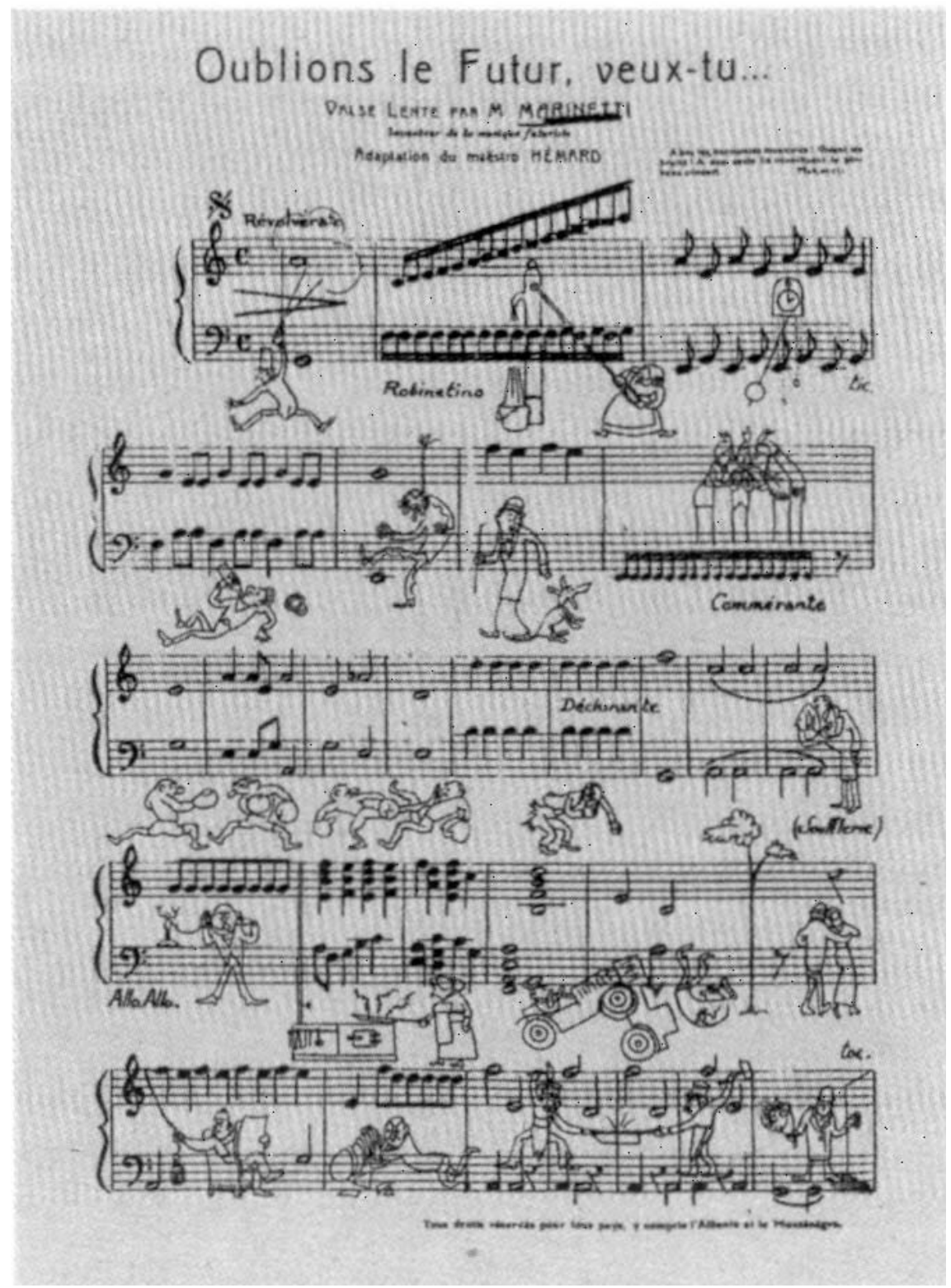

Afb. 1 Anonieme karikatuur Oublions le Futur, veux-tu... (1913). Bron: P. Hulten, Futurismo \& Futurismi, Milano, Bompiani, 1986 ,

p. 527

Centraal in dit geluidshistorisch artikel staat de vraag of het Futurisme wel zo luidruchtig was. Maakten geluiden en klanken en hun agressieve pendant - lawaai-inderdaad de kern van het Futuristische totaalproject uit? Aan de hand van de problematiek van de klanknotatie zal ik verschillende vormen van geluid aan bod laten komen. Deze analyse zal zich niet beperken tot het muzikale terrein, maar ook andere disciplines doorkruisen, van de schilderkunst tot de poëzie. Paradoxaal genoeg zal blijken dat de toen nog 'stille' cinematografie een 
cruciale ingang is tot het beantwoorden van de vraag of het Futurisme al dan niet kan worden gelijkgesteld aan lawaai. ${ }^{4}$

De hierboven geciteerde Russolo is de sleutelfiguur van de Futuristische 'muziek' - of moeten we zeggen: 'lawaai' (rumore) of 'geluid' (suono)? Hij is de auteur van het manifest over de lawaaikunst (L'arte dei rumori, I9I3) en uitvinder van de lawaaimachines (intonarumori) waarmee hij in de jaren tien en twintig van de vorige eeuw de interesse wekte van modernistische componisten als Ravel, Stravinsky en Varèse. In tegenstelling tot zijn collega Balilla Pratella, die tussen I9I0 en I9I2 een drietal baanbrekende - doch minder radicale-muziekmanifesten publiceerde, was Russolo geen professioneel getrainde musicus. Zijn Futuristische carrière begon in de schilderkunst. Hij vormde samen met Umberto Boccioni, Giacomo Balla, Gino Severini en Carlo Carrà de eerste groep van Futuristische schilders, die in I9ıo achtereenvolgens Manifesto dei pittori futuristi (Manifest van de Futuristische schilders) en La pittura futurista. Manifesto tecnico (Technisch manifest van de Futuristische schilderkunst) lanceerden en zich op die manier als eersten achter Marinetti schaarden.

\section{Van geluidenschilderkunst tot kleurenmuziek}

Het is opmerkelijk hoe de Futuristische schilders in hun technisch manifest naar de 'muzikaliteit van lijnen' en de 'polyfonie van de muziek' verwijzen. Daarbij pleiten ze voor een zingende en schreeuwende schilderkunst:

'De tijd is voorbij om onze picturale sensaties te fluisteren. Wij zullen ze laten zingen en roepen op onze doeken die oorverdovende en triomfantelijke fanfares schallen."

Carlo Carrà heeft de idee van een lawaaierige schilderkunst verder uitgewerkt in La pittura di suoni, rumori e odori (De schilderkunst van geluiden, rumoeren en geuren, I9I3). In dit manifest wordt stelling genomen tegen het concept van de kleurenharmonie, tegen het schone en het gracieuze van de rococostijl à la Watteau. Deze Franse schilder had aan het begin van de achttiende eeuw het genre van de 'fêtes galantes', idyllische taferelen van de gegoede stand in 'zoete' kleuren, gelanceerd. Volgens Carrà moest de tendens van de lieflijkheid worden ingeruild tegen 'vloekende' kleuren. ${ }^{6}$

Musica (I9II) (afb.2) een van Russolo’s bekendste schilderijen, is een goed staaltje geluidenschilderkunst ('pittura di suoni') te noemen. In deze gigantische compositie $(225 \mathrm{x}$ I40 cm) beoogt Russolo een picturale vertaling te geven van een geluidsgolf die voortkomt uit een muziekinstrument met klavier (een piano of orgel). Met 'vloekende' kleuren maakt hij deze voor het menselijk oog niet-waarneembare bewegingen zichtbaar. De geluidsgolf is weergegeven in een donkerblauwe golvende beweging, terwijl de resonantie wordt gesugge- 


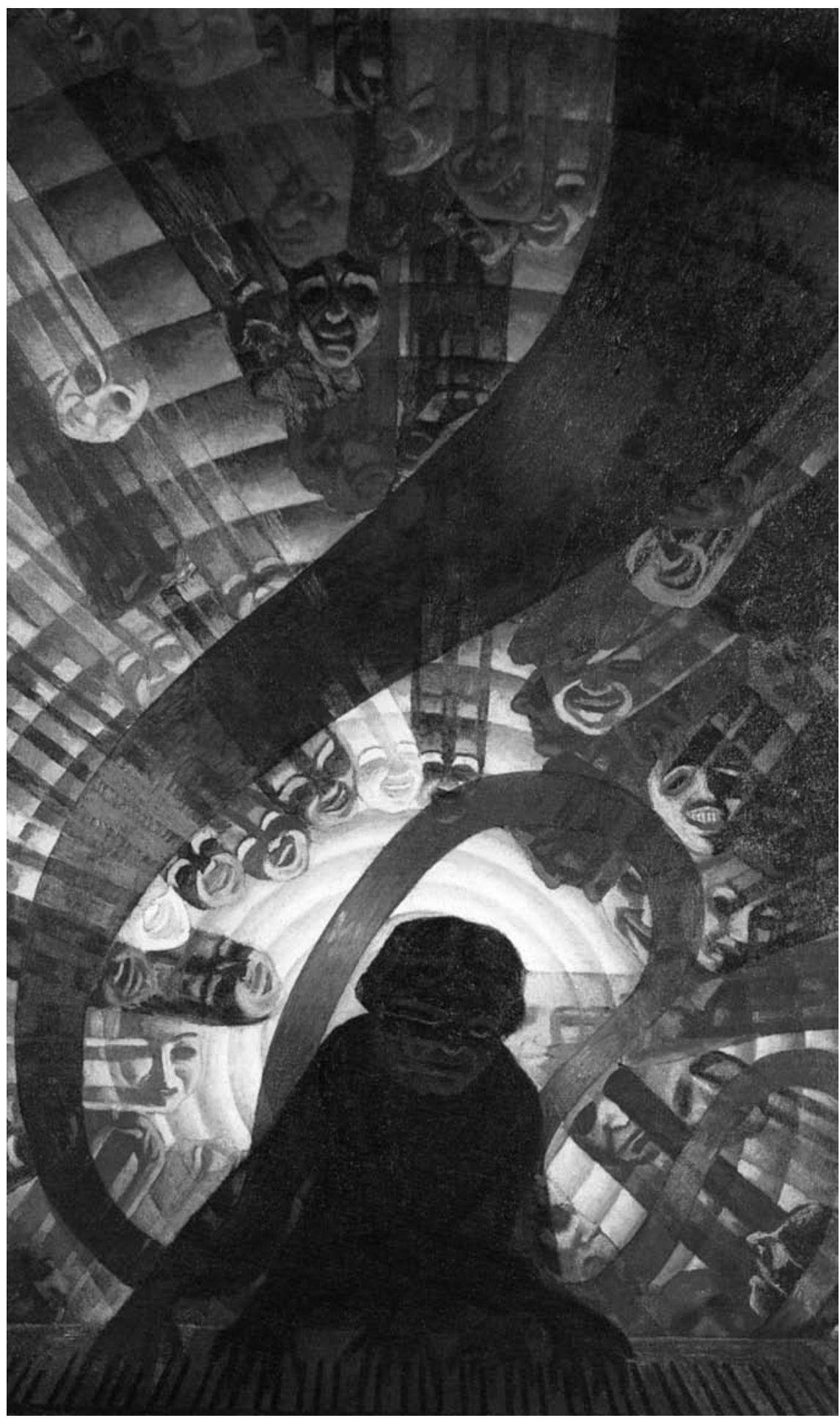

Afb. 2 Luigi Russolo, Musica (1911). Bron: P. Hulten, Futurismo \& Futurismi, Milano, Bompiani, 1986 , p. 205 
reerd met concentrische cirkels die gebroken worden door stralen in een viertal verschillende kleuren: rood, groen, geel en violet. Deze stralen, die hun oorsprong vinden in bevreemdende, in grimassen vertrokken, wellicht vloekende gezichten, doorkruisen de geluidsgolf die zich geleidelijk voortplant en verbreedt. Op de voorgrond zit een pianist (of organist) die het klavier bespeelt met vijf handen: een dergelijke verdubbeling van ledematen is typerend voor de Futuristische schriftuur van de beweging of 'cinegrafie', die vooral werd beoefend door de schilder Giacomo Balla. Deze stijl is op te vatten als een letterlijke toepassing van een van de bekendste formules uit het Technisch manifest van de Futuristische schilderkunst: 'een galopperend paard heeft geen vier poten, maar twintig'. In Russolo's werk ontstaat verder een interessant effect wanneer de felgekleurde stralen door de donkerblauwe geluidsgolf heen dringen. We krijgen geen echte vermenging of versmelting van kleuren, maar eerder een transparantie die sterk doet denken aan de filmische techniek van de overvloeier of dubbeldruk.

Volgens Caroline Tisdall en Angelo Bozzolla is dit schilderij een wat lompe poging om geluid te visualiseren. Ze zijn van mening dat Russolo's ware genie zich pas ontpopt vanaf I9I3, wanneer hij zich volledig in de muziekwereld stort. ${ }^{8}$ Een opmerkelijk detail lijkt me dat precies in dezelfde periode waarin Russolo aan dit immense geluidenschilderij werkte, er in de marge van het Futurisme nog andere pogingen werden ondernomen om muziek in kleur om te zetten. Dat gaat wel om een totaal andere notatie: niet op doek, maar op film.

Tussen ı9ıо en ı9ı2 realiseerden Arnaldo en Bruno Ginanni-Corradini, twee broers van adel en afkomstig uit Ravenna, zes abstracte kleurfilmpjes, die zowel nationaal als internationaal tot de eerste manifestaties van abstracte filmkunst worden gerekend. ${ }^{9}$ Dit pionierswerk, waarvan helaas geen enkel fotogram bewaard is gebleven, kwam tot stand door rechtstreeks op de filmstrook te schilderen na de gelatinelaag ervan te hebben verwijderd. Kortom, een vrij simpele vorm van animatie. We zouden ook kunnen spreken van 'schilderfilm', als alternatief voor 'tekenfilm'. De twee broers splitsten het kleurenspectrum op in chromatische eenheden of kleurtonen, die ieder voor een bepaalde muziektoon stonden. Op die manier kon muziek in kleur worden gerealiseerd. Het gaat hier dus om 'chromatisch' in de betekenis van 'gekleurd' (en niet in de muzikale betekenis van halftonen).

Bruno, de jongste van de twee broers, heeft de verschillende fasen van dit experiment beschreven in het essay Musica cromatica, dat in I9I2 is opgenomen in het eerste deel van de reeks Il pastore, il gregge e la zampogna (De herder, de kudde en de doedelzak), gepubliceerd te Bologna door Beltrami. Op basis van deze beschrijving zijn de titels van de eerste vier filmpjes post factum geconstrueerd: ACCORDO DI COLORE (Kleurenakkoord, I9II), geïnspireerd op een schilderij van Giovanni Segantini, aanhanger van het laat-negentiende-eeuwse Italiaanse divisionisme, een variant van het Franse pointillisme; STUDIO DI EFFETTI TRA QUATTRO COLORI (Studie van effecten tussen vier kleuren, I9II), 
gebaseerd op het spel tussen twee kleurenkoppels, rood-groen en blauw-geel; CANTO DI PRI MAVERA (Lentelied, I9II), een vertaling in visuele muziek van het Frühlingslied van Mendelssohn; en LES FLEU RS (De bloemen, I9II), een adaptatie van het gelijknamige gedicht van Stéphane Mallarmé. De titels van de twee laatste filmpjes, die iets langer dan de andere duurden (ca. acht minuten), heeft Bruno zelf aangebracht: L'A R Cо BALE No (De regenboog, I9I2), een visuele symfonie van regenboogkleuren tegen een contrasterende grijze achtergrond; en LA DANZa (De dans, I9I2) met karmijn, violet en geel. ${ }^{\text {Io }}$

Naar het schijnt zijn de filmpjes nooit vertoond, zelfs niet in intieme kring. Voor de broers Ginanni-Corradini betekende de cinematografie slechts een methode om tot een beter begrip van de verhoudingen tussen de kunsten te komen. Het was louter een onderzoeksinstrument. Ze gebruikten de cinema als middel, als notatiesysteem, en dus niet als doel op zich. ${ }^{\text {II }}$

Ginanni-Corradini's 'chromatische muziek' is strikt genomen een vorm van schilderkunst. Net als in Russolo's Musica, gaat het ook hier om het noteren van klanken, het in kleuren vastleggen van tonen die zich voortbewegen in de tijd. Waar Russolo opteert voor de methode van het plastisch dynamisme (in de lijn van Balla's cinegrafie) met effecten zoals de verdubbeling van de handen en de verbreding van de geluidsgolf - een visuele imitatie van een muzikaal crescendo -, doen de twee broers een beroep op de filmtechniek die door een opeenvolging van I 6 à 24 stilstaande beelden de illusie van beweging schept, althans tijdens projectie. De kleurenmuziek beweegt dus werkelijk, de geluidenschilderkunst suggereert beweging. Beide expressievormen zijn - laten we het benadrukken - geluidloos. Een belangrijke overeenkomst is het principe dat aan een bepaalde klank een bepaalde kleur wordt gekoppeld en dat het samenklinken van tonen kan worden vertaald in chromatische akkoorden, die bovendien vaak gevormd worden door complementaire kleuren (met name het kleurenkoppel rood-groen is opvallend aanwezig). Deze complementaire kleuren doen op hun beurt, volgens de algemene kleurenleer, de tonaliteit wit ontstaan. Dus, een kleurloze, geluidloze muziek? Een vorm van 'abstracte' muziek? ${ }^{12}$

Alvorens te experimenteren met film, hadden de broers Ginanni-Corradini een chromatische piano gebouwd, waarvan het klavier bestond uit 28 toetsen die elk met een gekleurde lamp waren verbonden; het bespelen resulteerde in een (geluidloos) lichtspel van kleuren. Hun filmische composities die daarop volgden, kunnen worden beschouwd als de notatie van de 'muziek' geproduceerd door deze chromatische piano.

Dit soort zoeken naar het vertalen van muziek in kleur beperkte zich niet tot de context van het Italiaanse Futurisme; vergelijkingen zijn bijvoorbeeld te trekken zowel met het symfonische gedicht voor lichtorgel Prometheus (I9I0) van Alexander Skrjabin, ${ }^{\mathrm{I}}$ als met de kleurenstudie voor film Rythme coloré (I9I2I9I4) van Léopold Survage. ${ }^{\text {I4 }}$ In het onderzoek van de broers Ginanni-Corradini stond echter niet alleen de interrelatie van kleur en muziek centraal. Ze geloofden in een exacte overeenkomst (of evenredigheid) tussen alle kunsten. Zo was 
de divisionistische (of pointillistische) schilderkunst van Segantini een vertrekpunt om te komen tot

'studies van het Chromatisch Akkoord, de Chromatische Symfonie, enzovoorts, want de verschillende puntjes of streepjes vormden inderdaad een overeenkomst met de verschillende muzieknoten. (...) Voorbeeld: een "kleurenzone" in een weide in een schilderij van Segantini was een uit de natuur gegrepen chromatisch akkoord, gegrepen uit de bergweiden. ${ }^{\text {,5 }}$

Het principe van de overeenkomsten tussen alle kunstvormen, waardoor synesthetische kunstbeoefening (en -ervaring) mogelijk is, ligt ten grondslag aan de Futuristische 'polyexpressiviteit', een fundamenteel concept voor het Futuristische filmproject dat vijf jaar na Ginanni-Corradini's chromatische muziekexperiment van start gaat in de context van het zogenoemde tweede Florentijnse Futurisme. ${ }^{16}$ De 'polyexpressiviteit' beoogt een soort totaalkunst, een Futuristisch spektakel, waarin alle mogelijke expressiemiddelen met elkaar interageren op een zeer vrije - dit wil zeggen: disharmonische, onesthetische, chaotische manier. Kortom, een subversieve vorm van het Wagneriaanse Gesamtkunstwerk.

Wagners ideeëngoed is, zoals voor vele andere kunstenaars aan het begin van de twintigste eeuw, zeker ook van belang geweest voor Arnaldo en Bruno Ginanni-Corradini. In hun traktaat Arte dell'avvenire (Kunst van de toekomst, I9I0; heruitgebracht in herziende versie in I9II ${ }^{\text {I7 }}$ ) zijn ze echter niet eenduidig in hun oordeel over de auteur van Das Kunstwerk der Zukunft (I860): de passages waarin Wagner wordt aangehaald schommelen tussen lofrede en ridiculisering. Zo beweren de broers in hun traktaat dat de Duitse componist een 'correcte kennis van de overeenkomsten tussen de verschillende kunsten' miste en citeren ze zijn 'Zukunftsmusik' als voorbeeld van een 'overduidelijk foute' theorie met betrekking tot de wederzijdse relaties tussen de kunsten. ${ }^{\text {I8 }}$ Maar anderzijds formuleren ze ook op vrij Wagneriaanse wijze hun centrale idee: 'De essentie van alle kunsten is één, veel zijn de expressiemiddelen. ${ }^{\text {'9 }}$ Om deze unieke essentie te vatten, nemen ze de muziek als uitgangspunt en onderscheiden vier pure (essentiële) kunstvormen: $1^{\circ}$ Accordo (Akkoord); $2^{\circ}$ Motivo (Motief); $3^{\circ}$ Accordoimagine (Beeld-Akkoord); $4^{\circ}$ Motivo-imagine (Beeld-Motief). ${ }^{20}$ Deze vier basisvormen worden vervolgens toegepast op de kunst der kleuren (= schilderkunst), de kunst der vormen (= beeldhouwkunst), de kunst der lijnen (= architectuur) en de kunst der woorden (= literatuur). De gebroeders Ginanni-Corradini streven echter niet zoals Wagner naar een fusie of synthese van de kunsten: hun doelstelling is om via de essentie van de muziek tot een purificatie van de andere kunsten te komen. Dat is de gedachte die achter het experiment zit om muzikale akkoorden te transponeren in kleurenakkoorden, om aan de hand van de chromatische piano of de cinematografie kleuren in elkaar te laten vloeien zoals muziektonen dat doen - simultaan of successief, in een akkoord of in een motief. 
Ook al geloofden Bruno en Arnaldo niet in Wagners Gesamtkunstwerk, toch kozen ze een zeer Wagneriaans aandoende titel Arte dell'avvenire (Kunst van de toekomst) voor hun traktaat. De term 'avvenire' betekent echter niet alleen 'toekomst', maar ook 'gebeuren', 'voorvallen'. Het zou kunnen verwijzen naar het gebeuren in de zin van ontwikkeling (of vorming) van vormen, een concept dat centraal staat in het werk van de decaan van de Futuristische schilders, Umberto Boccioni, die niet toevallig interesse toonde voor Ginanni-Corradini's traktaat om hen vervolgens tot de club van de Futuristische schilders toe te laten. Deze recrutering ging gepaard met het Futuristisch omdopen van de twee adellijke broers tot Arnaldo Ginna (= ginnastica: gymnastiek) en Bruno Corra (=correre: lopen). Daar zowel hun schilderfilmpjes als hun theorie over de kunst van de toekomst dateren van vóór deze officiële erkenning door de Milanese kern, zijn ze moeilijk als volwaardig Futuristisch te beschouwen. Ginanni-Corradini's onderzoek is later wel geïntegreerd (gerecupereerd en gereduceerd) in het kader van de Futuristische film, meer bepaald in de volgende twee proposities van het manifest van de Futuristische cinematografie (I916):

4. Gefilmd muzikaal onderzoek (dissonanties, akkoorden, symfonieën van gebaren, feiten, kleuren, lijnen, enz.).

$[\ldots]$

I3. Gefilmde lineaire plastische, chromatische, enz. overeenkomsten van mannen, vrouwen, gebeurtenissen, gedachten, muziek, gevoelens, gewichten, geuren, geluiden (wij geven met witte lijnen op zwart het innerlijke ritme en het fysische ritme van een echtgenoot die zijn overspelige vrouw betrapt en de minnaar achtervolgt - ritme van de geest en ritme van de benen). ${ }^{21}$

Arnaldo en Bruno introduceerden niet alleen het concept van de chromatische muziek, maar ook - zoals hierboven reeds gezegd - een nieuwe, onorthodoxe interpretatie van het Wagneriaanse Gesamtkunstwerk die belangrijk bleek voor de ontwikkeling van de 'polyexpressiviteit'. Indirect hebben hun bevindingen over de 'kunst van de toekomst' de weg dus vrijgemaakt voor de Futuristische film.

Graag wil ik hierbij onderstrepen dat de filmkunst niet expliciet aan de orde komt in Arte dell'avvenire. In dit traktaat gaat het in de eerste plaats om de schilderkunst. Hoewel de chromatiek door de twee broers uitsluitend in termen van kleur wordt uitgewerkt, is het ook mogelijk hun theorie te interpreteren in strikt muzikale termen, namelijk van 'halve, niet laddereigen, toonafstanden', ${ }^{22}$ en op die manier in verband te brengen met Wagners chromatische stijl. In Bruno's essay Musica cromatica duiken bovendien voortdurend termen op zoals thema en motief, respectievelijk geïnspireerd op, of althans verwant aan, de Wagneriaanse Grundthemen en Leitmotive. De chromatische stijl van GinanniCorradini's filmische experimenten is tegelijkertijd ook te relateren aan de microtonaliteit van de Futuristische muziek. Dit principe werd in I9I2 door Pratella aangekondigd in zijn derde muziekmanifest, La distruzione della qua- 


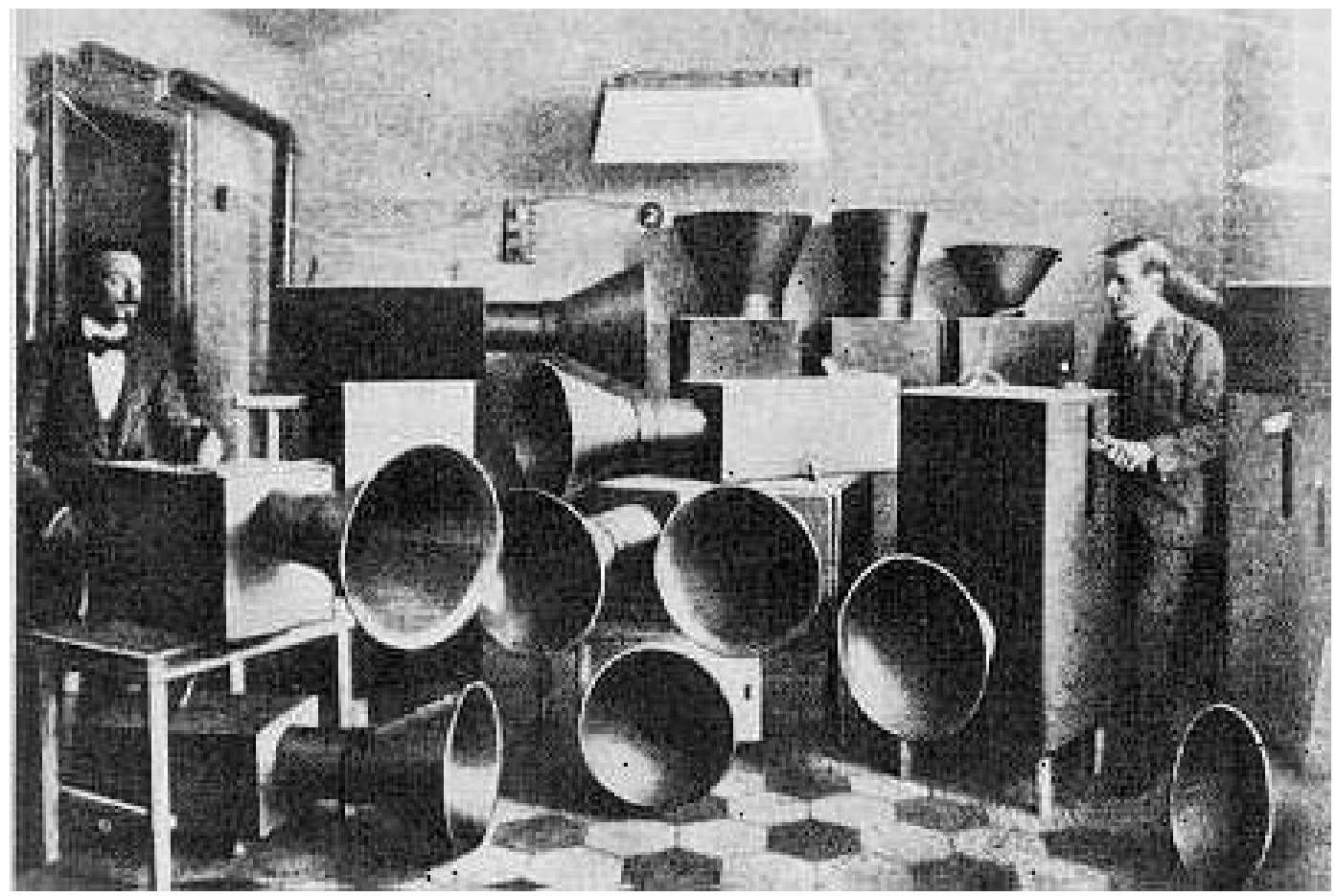

Afb. 3 Luigi Russolo en Ugo Piatti met hun intonarumori. Bron onbekend

dratura (De vernietiging van de kwadratuur), waarin hij pleitte voor de bevrijding van de muziek uit de canons van de klassieke harmonie 'door middel van atonaliteit, ritmische onregelmatigheid en intervallen die kleiner zijn dan de halftoon'. ${ }^{23}$ Wanneer deze intervallen 'minder bedragen dan $1 / 4$ van een hele toon', spreekt men van microtonen. ${ }^{24}$

\section{Futuristische grondslagen van de musique concrète en de concrete poetry}

In juni I9I3 lanceerde Russolo zijn ‘ontploffer' (scoppiatore): dit eerste specimen van de intonarumori kon het geluid van een verbrandingsmotor nabootsen in een 'toonladder' van tien hele tonen. Samen met Ugo Piatti bouwde Russolo nog een reeks andere herriemakers, zoals gorgelaars (gorgoliatori), knetteraars (crepitatori), loeiers (ululatori), dreuners (rombatori), gonzers (ronzatori), sissers (sibilatori) en wrijvers (stropicciatori) (afb. 3).

De onomatopoëtische dimensie van deze instrumenten is overduidelijk, maar hoe valt hiervoor muziek te componeren en hoe is deze lawaaimuziek te noteren? In maart I9I4 stelde Russolo in het Futuristische tijdschrift Lacerba een nieuw notatiesysteem voor: de traditionele muzieknoten werden vervangen door een numeriek systeem en voor het aanduiden van tonale continuïteit 
werden doorlopende lijnen in vette druk geïntroduceerd. Van de partituur van Russolo's lawaaicompositie Veglio di una città (Ontwaken van een stad, I9I4) zijn slechts twee pagina's bewaard (afb. 4).

Hiervan kunnen we afleiden dat sommige lawaaimachines verschillende - al dan niet ver uit elkaar liggende (en in twee sleutels genoteerde) - tonen simultaan konden produceren, terwijl andere, zoals bijvoorbeeld de wrijvers en de gonzers, dat niet konden. Het (letterlijke en figuurlijke) steunpunt voor het noteren van de microtonaliteit blijft wel degelijk de traditionele notenbalk, maar de noten zijn niet meer van elkaar gescheiden: ze vloeien in elkaar over, van de ene microtoon naar de andere, in een continue lijn.

Wanneer we Russolo's lawaaicompositie vergelijken met Pratella's Gioia (Vreugde, I9I4) (afb. 5), valt meteen op dat deze laatste is geschreven voor 'gemengd orkest'. Pratella combineert een drietal notatiesystemen, respectievelijk voor de menselijke stem, de lawaaimachines (met name de eenstemmige ontploffers en gonzers) en traditionele orkestinstrumenten. Zowel de menselijke stem als de intonarumori vertonen weinig variatie: de massa ('Gente') roept af en toe een kreet ('Ohe!') en de muzikale capaciteit van Russolo's machines wordt door Pratella als het ware gereduceerd tot monotonaliteit. De notenlijnen verlopen vaak over verscheidene muziekmaten horizontaal en worden bovendien nooit onderbroken (in tegenstelling tot het meer ontploffende of explosieve karakter van de scoppiatore in Russolo's Veglio di una città). Pratella voorziet in deze monotonaliteit wel enkele variaties die aangeduid worden door stippen of schuine streepjes onder en boven de notenlijn; deze notaties staan voor mol-, kruis- en herstellingstekens.

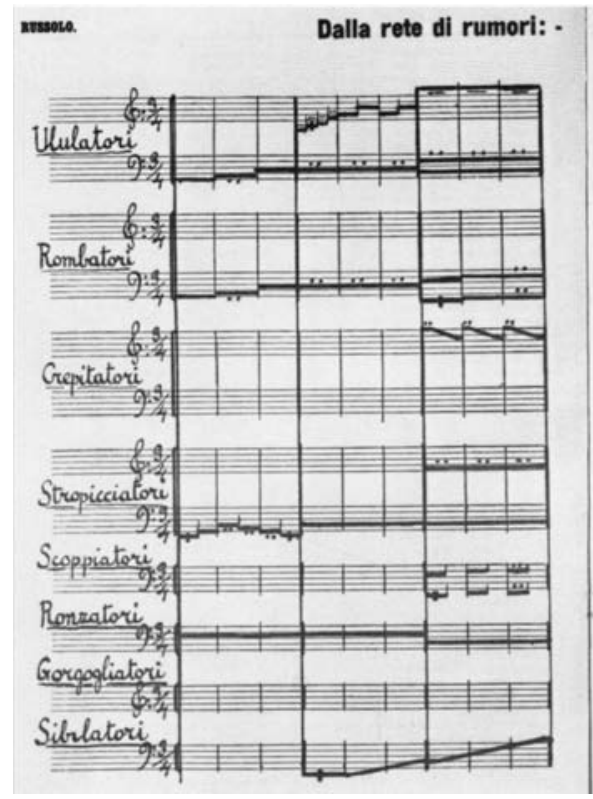

VEGLIO DI UNA CITTA.

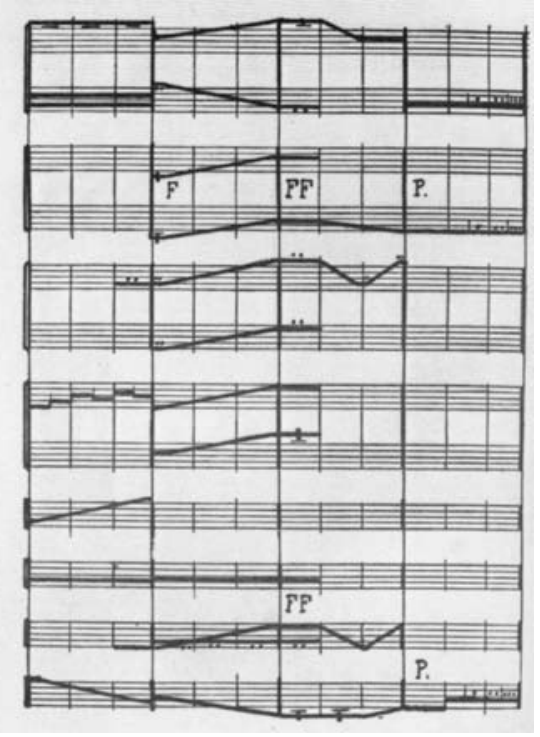

Afb. 4 Luigi Russolo, Veglio di una città (1914). Bron: Futurismo igog-Igig. Exhibition of Italian Futurism, Newcastle, 1972, p. 100 
In tegenstelling tot Russolo's lawaaicomposities blijven Pratella's muziekstukken voor gemengd orkest verankerd in een traditionele vorm van muziek waaruit ritmische regelmaat en harmonie niet volledig zijn verbannen en waarin de intonarumori worden herleid tot een nieuwe categorie muziekinstrumenten die voor special sound effects zorgen. In feite ging Pratella's theorie veel verder dan wat hij in de praktijk heeft gecomponeerd aan Futuristische muziek; misschien belette zijn vertrouwdheid met de principes van de klassieke harmonie hem om zich hiervan los te maken en tot een muzikale revolutie te komen. Dit verklaart waarschijnlijk ook waarom het bescheiden succes van de Futuristische muziek uitsluitend verbonden blijft aan de naam van Russolo, die zich als niet-professionele musicus radicaler heeft weten op te stellen. Zijn lawaaimuziek is immers niet langer gebaseerd op noten van verschillende toonhoogtes, maar op 'geluiden die relateerbaar zijn aan, zonder simpele imitaties te zijn van, rumoeren uit onze dagelijkse ervaring'. ${ }^{25}$ Hierbij kunnen we denken aan allerlei modernistische stadsgeluiden, fabriek- en stoombootsirenes, knarsende trams, explosieve automotoren, gefluit, geroezemoes, geroep... De basis voor Russolo's Futuristisch orkest is een zestal geluidenfamilies, die elk door specifieke machines kunnen worden geproduceerd. Klassieke muziekinstrumenten komen in dit systeem niet tot hun recht. Russolo's
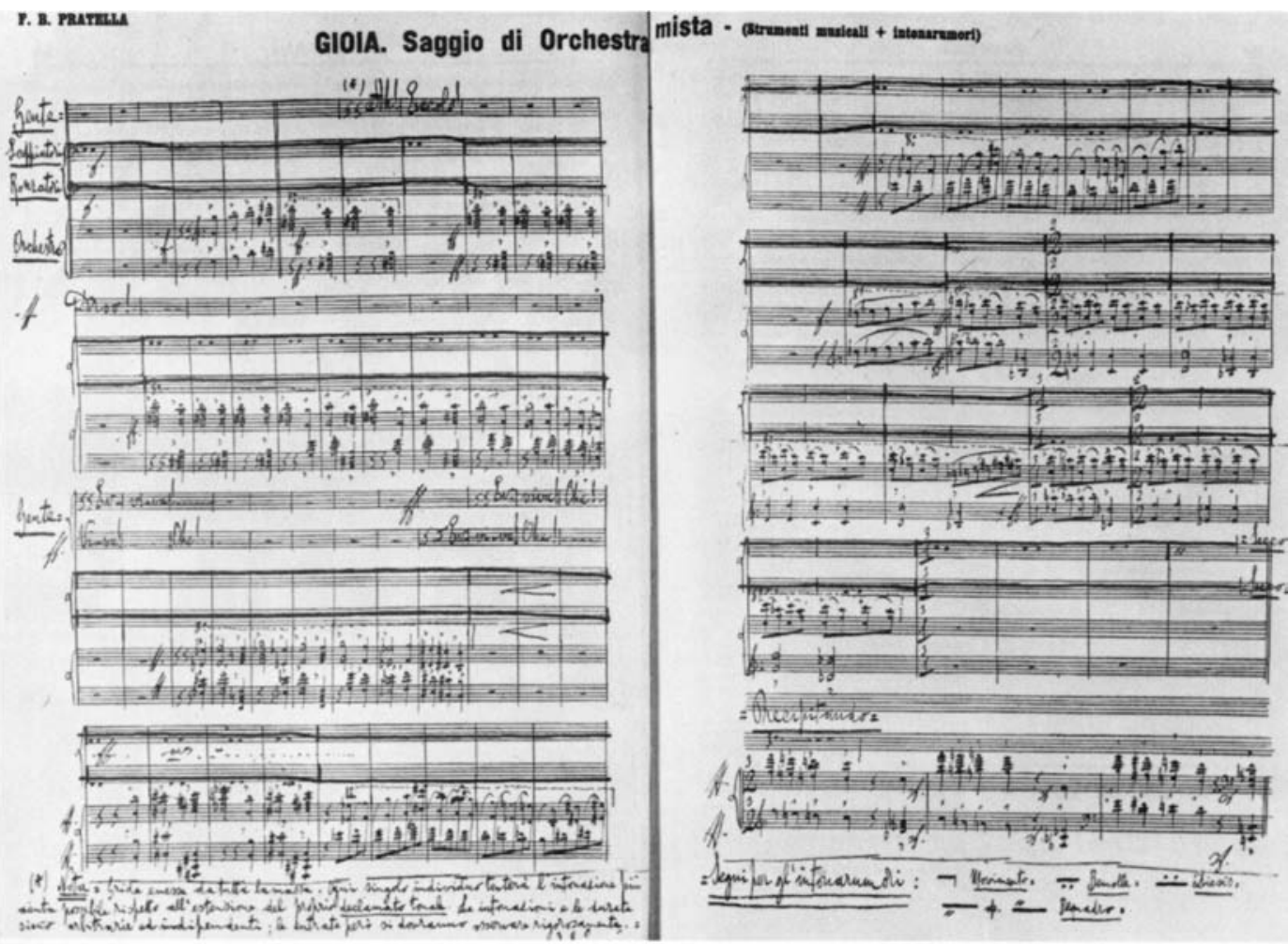

Afb. 5 Ballila Pratella, Gioia (1914). Bron: Futurismo I909-I9I9. Exhibition of Italian Futurism, Newcastle, 1972, p. 101 
muziek is geen muziek voor 'gemengd orkest', maar een 'netwerk van geluiden' (rete di rumori).

Russolo was de eerste componist die probeerde concrete geluiden, van natuurlijke en mechanische oorsprong, te gebruiken als eenheden voor muziek: deze geluiden, gegrepen uit ons dagelijks leven, zijn dus niet louter een inspiratiebron, maar direct materiaal. Russolo moest het notatiesysteem daarom wel veranderen. Omwille van deze relatie met (en let wel: geen 'slaafse imitatie ${ }^{26}$ van) natuurlijke geluiden kan Russolo's lawaaikunst beschouwd worden als voorloper van de musique concrète van de jaren vijftig. Deze vorm van muziek, geïntroduceerd door Pierre Schaeffer, is 'opgebouwd uit concrete klankvoorwerpen', die door montage en mixage worden gemanipuleerd. ${ }^{27}$

Zoals Russolo in de muziekgeschiedenis kan worden gezien als pionier van de musique concrète, is in de literatuurwetenschap Marinetti's poëzie van woorden-in-vrijheid te beschouwen als een eerste vorm van concrete poetry, of althans als voorganger van deze in de jaren vijftig in Brazilië gelanceerde poëtische beweging. Binnen de context van het Futurisme zelf wordt Russolo's lawaaikunst vaak vergeleken met Marinetti's paroliberismo of kunst van woorden-in-vrijheid: het zouden beide even baanbrekende theorieën (en praktijken!) zijn geweest op respectievelijk het muzikale en het poëtische terrein, twee revolutionaire golven die klassieke regels (van de harmonie en van de syntaxis) werkelijk hebben weten te vernietigen en die tot ver buiten het Futurisme hun weerklank hebben gevonden.

Het project van de woorden-in-vrijheid brengt Marinetti in eerste instantie theoretisch in kaart met een reeks van manifesten - Manifesto tecnico della letteratura futurista (Technisch manifest van de Futuristische literatuur, I9I2), Distruzione della sintassi - Immaginazione senza fili - Parole in libertà (Vernietiging van de syntaxis - Draadloze verbeelding - Woorden in vrijheid, I913), Lo splendore geometrico e meccanico e la sensibilità numerica (De geometrische en mechanische pracht en de numerieke gevoeligheid, I9I4) - om het vervolgens tot volle (creatieve) uiting te laten komen in het oorlogsepos Zang Tumb Tumb (I9I4). In I9I2 krijgt de Futuristische lezer echter al een voorproefje te zien (!) in het uittreksel Battaglia Peso + Odore (Veldslag Gewicht + Geur) dat Marinetti opneemt in het supplement van het Technisch manifest van de Futuristische literatuur, waarin hij antwoorden formuleert op de bezwaren die ondertussen in de pers zijn verschenen. De woorden-in-vrijheid waaruit deze 'veldslag' is samengesteld zijn woorden-in-vrijheid stricto sensu: het is een vloed van losse woorden, bevrijd uit de ketens van de syntaxis, de interpunctie, de metriek en zelfs van het vrije vers. Deze bevrijde woorden zijn aaneengeschakeld ofwel door de nominale analogie (Futuristische stijlfiguur die twee substantieven aan elkaar 'monteert' door een koppelteken), ofwel door de zogenaamde 'numerieke gevoeligheid' (die zich manifesteert in wiskundige tekens). De structuur blijft traditioneel lineair, maar door het gebrek aan interpunctie en syntaxis vloeien de woorden als het ware in elkaar over in een continue, razende stroom. Met 
regelmaat treden er in deze onstuitbare woordenvloed typografische leegtes op, alsof er planmatig telkens een woord is uitgewist. Deze witte vlekken zorgen voor een visueel effect, ze veruiterlijken het beweeglijke (zigzaggende) ritme van de tekst. Om tot dit soort 'lectuur' te komen moet de lezer de tekst niet lezen, maar bekijken; hij of zij moet de woorden als linguïstische tekens abstraheren om de 'veldslag' te kunnen aanschouwen (afb. 6).

We zouden het kunnen vergelijken met het fixeren van een zwart scherm waarop kleine, beweeglijke rechthoeken verschijnen; een blauwdruk van de visuele geometrische muziek die in de jaren twintig zal worden vastgelegd op celluloid door Hans Richter, meer bepaald in zijn R HYTH M U S-serie (I92I-I925). We zouden tevens Arnaldo Ginanni-Corradini's woorden naar aanleiding van Segantini's pointillisme weer kunnen aanhalen: de (in dit geval witte) streepjes zouden dan overeenkomsten vormen met verschillende muzieknoten.

Maar al deze lezingen doen onrecht aan Marinetti's oorspronkelijke intentie die niet visualiserend maar sonoriserend is: zijn typografische experimenten

ferrailles tire-lire mollesse : 3 frissons commandements-pierres rage ennemi-aimant légèreté gloire héroïsme Avantgardes : 100 mètres mitrailleuses fusillade éruption violons cuivre pim poum pac pac tim toum mitrailleuses tatarataratarata Avant-gardes : 20 mètres bataillonsfourmis cavalerie-araignées routes-gués général-ilot estafettes-sauterelles sable-rérolution obus-tribuns nuages-grils fusils-martyrs shrapnels-auréoles multiplication addition division obus-soustraction grenade-rature ruisseler couler éboulement blocs avalanche Avant-gardes : 3 mètres mélange va-et-vient collage décollage déchirement feu déraciner chantiers éboulement carrières incendie panique aveuglement écraser entrer sortir courir éclaboussement Vies-fusées cœurs-friandises baïonnettes-fourchettes mordre dépécer puer valser bondir rage curée explosions obus-gymnastes fracas-trapèzes explosion rose joie ventres-arrosoirs têtes-foot-ball éparpillement Canon-149 éléphant artilleurs-cornacs hissa-hoo colère leviers lenteur lourdeur centre gargousse-jockey méthode monotonie trainers distance grandprix gueule parabole $x$ lumière tonnerre

Afb. 6 Bataille Poids + Odeur (1912). Bron: F.T. Marinetti, Les mots en liberté futuristes, Milano, Edizioni futuriste di 'Poesia' staan in de eerste plaats ten dienste van de declamatie. De witte rechthoeken in bovengenoemde compositie zouden dan het best geïnterpreteerd kunnen worden als rustpunten in de woordenvloed, als adempauzes voor de declamator. Marinetti zelf was een briljant redenaar en declamator (afb. 7).

Hij heeft gedurende zijn hele carrière performances gegeven in alle Europese metropolen: hij was een man van het spektakel, van het theatrale gebaar, die interactie zocht met zijn publiek. Provocatie was een van zijn belangrijkste strategieën, samen met een expressieve declamatie. In zijn derde literaire manifest De geometrische en mechanische pracht en de numerieke gevoeligheid legt Marinetti uit hoe 'de vrije, expressieve spelling en typografie' kunnen helpen om 'gezichtsmimiek en gesticulatie van de verteller' uit te drukken, om het woord als theatraal gebaar te ondersteunen. ${ }^{28}$ Zie ook zijn manifest La declamazione dinamica e sinottica (De dynamische en synoptische declamatie, I9I6), waarin hij zijn nieuwe declamatiekunst als 'lyrische sport' introduceert. ${ }^{29}$ Marinetti's benadering is te vergelijken met die van de concrete poetry aanhangers, voor wie poëzie - naar James Joyce's neologisme - 'verbivocovisual' moet 
zijn: poëzie voor het oog en voor het oor, om gezien en gehoord te worden..$^{30}$ Belangrijk voor mijn betoog is dat Marinetti systematisch heeft gepoogd om met een niet-traditionele typografie richting te geven aan de declamatie.

Hierin ligt de paradox van Marinetti's poëtica: hoewel hij met zijn woorden-in-vrijheid de basis legt voor de visuele poëzie, is het hem vooral te doen om de oraliteit. Zijn aandacht is voortdurend gericht op de akoestische dimensie; met zijn woorden-in-vrijheid wil hij de kenmerkende onmiddellijkheid van de orale expressie vatten. Teksten zoals Zang Tumb Tumb en Battaglia di Adrianopoli, vol bombardementen en explosies, zijn eigenlijk gecomponeerd als 'declaimable scores.'..$^{31} \mathrm{On}$ danks hun uiterst visuele dimensie zouden ze dan ook het best kunnen worden gelezen als geluidsmontages (en niet als beeldmontages), als onomatopoëtische gedichten die bedoeld waren om voorgedragen te worden tijdens Futuristische avonden (serate). Vanwege het gebruik van deze geluidseffecten verwierven de Futuristische dichters snel de pejoratieve bijnaam 'futuristi del bumbum'. ${ }^{32}$
AN IMPRESSION OF THE FUTURIST LEADER.

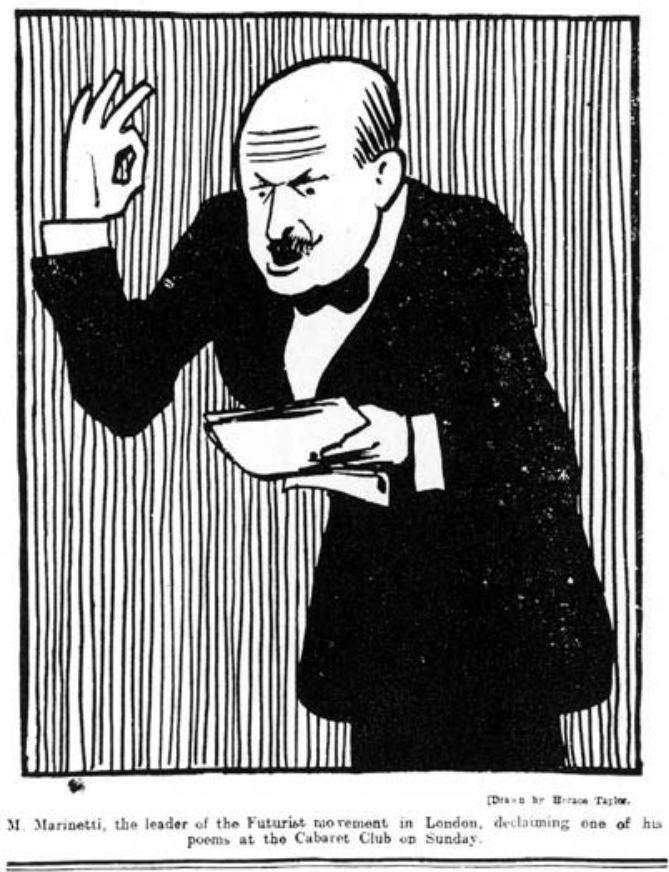

Afb. 7 Karikatuur van Marinetti door Horace Taylor Bron: P. Hulten, Futurismo \& Futurismi, Milano, Bompiani, $1986, p \cdot 501$

Michael Webster heeft in zijn Reading Visual Poetry after Futurism zeer nadrukkelijk gewezen op de paradoxale implicaties van Marinetti's typografische revolutie. ${ }^{33}$ Marinetti beoogde volgens hem de akoestische dimensie van de woorden-in-vrijheid te verhogen, te intensiveren door een visueel mimetische typografie. Tegelijkertijd verachtte Marinetti het puur visuele effect: in De geometrische en mechanische pracht onderstreepte hij de noodzaak om 'elke picturale bekommernis te vermijden, om geen behagen te vinden in een spel van lijnen noch in curieuse typografische wanverhoudingen'. De typografische effecten mochten dus 'geen doel zijn, maar een middel om de expressieve kracht van het lyrisme te verhogen' ${ }^{34}$ Ook hier is een parallel met Ginanni-Corradini's experiment te trekken. Filmische notatie was voor de twee broers geen doel, maar een middel om tot een beter begrip van de overeenkomsten tussen de kunsten te komen. Marinetti's typografische notatie staat ten dienste van de oraliteit, in zoverre dat het de onmiddellijke gewaarwording vergroot en de werkelijkheid dichter bij de lezer-toeschouwer brengt.

Dit ambitieuze poëtische project leidt onvermijdelijk tot de ontsporing van de verhouding tussen signifiant (het betekenende, het akoestische beeld van de 
betekenis) en signifié (het betekende, het mentale beeld van de betekenis). Volgens de algemene linguïstiek van Ferdinand de Saussure is deze verhouding gebaseerd op conventies, en dus arbitrair. ${ }^{35}$ Dit willekeurige karakter wordt in het Futuristische paroliberismo ontbonden ten voordele van de iconiciteit of expressiviteit van het linguïstische teken. Het is belangrijk om te benadrukken dat Marinetti zijn nieuwe poëtische taal ontwikkelde precies op het moment dat de Saussuriaanse beginselen weerklank kregen in de linguïstiek. ${ }^{36}$ Marinetti ging tegen deze beginselen in door het representatievermogen van het woord te herwaarderen en de wederzijdse afhankelijkheid tussen signifiant en signifié, die volgens De Saussure niet wezenlijk was, juist centraal te stellen. Zonder te diep in te gaan op de problematiek van Marinetti's anti-Saussuriaanse instelling, ${ }^{37}$ wil ik hier het ambigue statuut dat hij aan de signifiant toekent beklemtonen: als de signifiant zich enerzijds lijkt los te werken van de signifié om een concrete vorm aan te nemen en zich visueel te transformeren, blijkt anderzijds dat hij meer dan ooit bepaald wordt door het mentale beeld of, beter, door de extralinguïstische werkelijkheid: de referent. Dit wordt vooral benadrukt door de zogenaamde 'getekende analogieën' die gevormd worden door woorden-in-vrijheid die de extralinguïstische werkelijkheid rechtstreeks lijken te imiteren. De Napolitaanse dichter Francesco Cangiullo gebruikt deze techniek van de 'getekende analogie' in zijn compositie Fumatori II ${ }^{a}$ (I9I4) wanneer hij voor het weergeven of re-presenteren van sigarettenrook de letters die het werkwoord FUMARE (= roken) vormen in een visueel (typografisch) crescendo plaatst; en in Piedigrotta (I9I6) vervangt hij de letter O in het woord тRом в Е (= trompetten) door een viertal concentrische cirkels om op die manier de vibratie van de schallende klanken te visualiseren. Marinetti's Zang Tumb Tumb bevat een vergelijkbaar voorbeeld van typografische imitatie/re-presentatie van geluidsgolven: in het hoofdstuk 'Oorlogscorrespondenten en vliegeniers' wordt het toenemende lawaai van een vliegtuig dat door een 'plafond van wolken' heen dringt gevisualiseerd door een crescendo van de letters VRRRRRR. Een duidelijke aanwijzing voor de declamator dat hij het volume van zijn stem moet verhogen.

Onomatopeeën vormen een belangrijk expressiemiddel in Marinetti's poëtica. Naast de directe (imiterende, elementaire, realistische) en indirecte (complexe, analogische) onomatopeeën, reserveert de Futuristische dichter in zijn systeem ook een plaats voor de 'abstracte onomatopee, rumoerige, onbewuste uitdrukking van de meest complexe en mysterieuze bewegingen van onze sensibiliteit'. Als voorbeeld citeert hij zijn gedicht Dune, waarin de 'abstracte onomatopee ran ran ran met geen enkel natuurlijk of mechanisch geluid overeenkomt, maar een uitdrukking is van een gemoedstoestand.$^{38}$ Dus, zoals Russolo, beoogde ook Marinetti in theorie geen slaafse imitatie van de werkelijkheid; in de praktijk echter nemen de 'imiterende' of 'elementaire' onomatopoëtische effecten de overhand.

Ik zou nog een reeks voorbeelden van typografische geluidsnotaties kunnen bespreken, zoals de Carta sincrona (dei suoni rumori colori immagini odori speranze 


\section{CARTA SINCRONA}

\section{dei suoni rumori colori immagini odori \\ speranze voleri energie nostalgie \\ traceiata dall'aviatorg $Y$. M.}

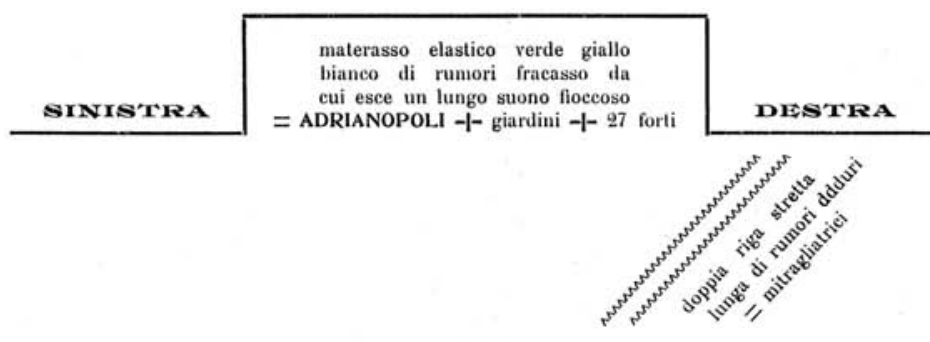

uovo di silenzio dorato = pallone frenato 0 donna incinta vestita di stoffe leggiere in riva al mare presa e ripresa dal vento

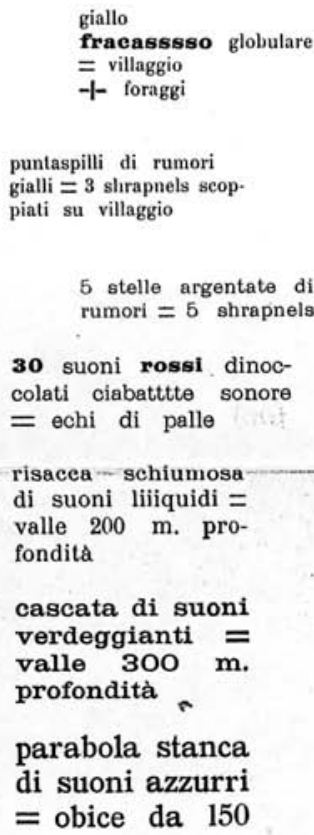

5 stelle argentate di

30 suoni rossi dinoccolati ciabattte sonore $=$ echi di palle

risacea - schiumosa di suoni liiiquidi = valle $200 \mathrm{~m}$. profondita

cascata di suoni verdeggianti = valle $300 \mathrm{~m}$. profondità

parabola stanca di suoni azzurri $=$ obice da 150

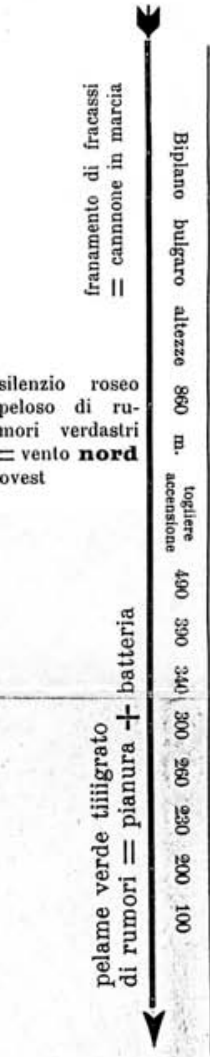
rumori $=5$ shrapnels bianco di rumori fracasso da

esce un lungo suono floccoso

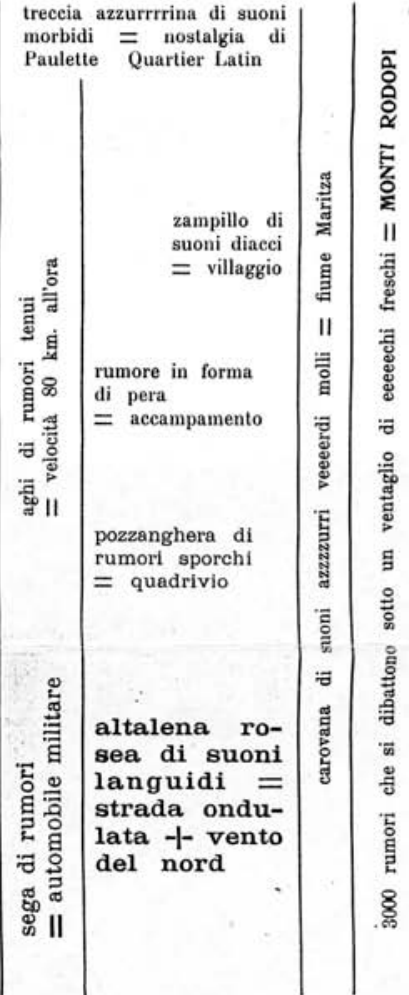

Afb. 8 Carta sincrona (dei suoni rumori colori immagini odori speranze voleri energie nostalgie tracciata

dall'aviatore Y. M.). Bron:

F.T. Marinetti,

Zang Tumb Tumb, Milano, Edizioni

Futuriste di

'Poesia', 1914 


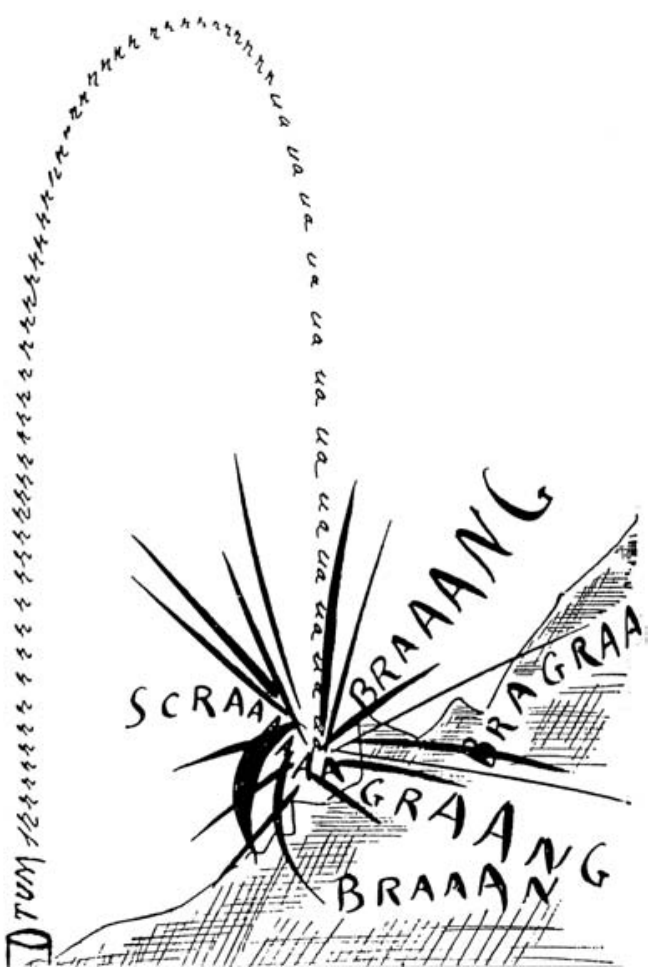

Afb. 9. F.T. Marinetti, 8 anime in una bomba: romanzo esplosivo, Milano, Edizioni futuriste di 'Poesia', 1919 voleri energie nostalgie tracciata dall'aviatore $Y$. M.) (Synchrone kaart (van geluiden rumoeren kleuren beelden geuren hoop wil energie nostalgie getraceerd door vliegenier Y.M.)) (afb. 8), een opvouwbaar dubbelblad uit Zang Tumb Tumb waar het traject van een vliegtuig door verschillende atmosferische lagen heen schematisch in kaart wordt gebracht en waar bepaalde kleuren staan voor bepaalde (toon-) hoogtes. Of de spectaculaire ontploffing van de bom aan het einde van Marinetti's 'explosieve roman' 8 anime in una bomba (8 zielen in een bom, I9I9) (afb. 9) waar onomatopoëtische woorden-in-vrijheid ('TU m rrr... ua ua ua ua...') het parcours van het explosief volgen tot het bij aanraking van de grond ontploft: de beweging van de bom wordt dus zowel gevisualiseerd als gesonoriseerd.

Een ander mooi voorbeeld is Carrà's schets Cineamore (Filmliefde, I9I4) (afb. Io) waar we een vloed van moeilijk leesbare woorden te zien krijgen die op regelmatige afstand wordt onderbroken door een opeenvolging van kleine, rollende r's. Deze 'geletterde' strepen, die volgens Carrà's aanwijzing in vette druk moeten worden geplaatst, lijken het continue en dreunende geluid van de cinematograaf, van het gedrrrrrrrrrrraai tijdens opname en projectie, te willen imiteren. Ten tijde van de stille film was de cinematograaf allesbehalve geluidloos: het was een van de vele stemmen in het 'kakofonische koor van de moderniteit'. ${ }^{9}$

Futuristische woorden-in-vrijheid kunnen door een bepaalde typografie, gedrukt of geschreven, een duidelijk sonoriserende dimensie krijgen toegeschreven; ze worden op die manier - net zoals muzieknoten - geconventionaliseerde visuele tekens, die richting moeten geven aan de declamatie (van beeld naar klank). Ginanni-Corradini's chromatische akkoorden daarentegen vormden gevisualiseerde muziek, die in de eerste plaats was bedoeld voor het oog en niet voor het oor (van klank naar beeld).

\section{Futuristisch lawaai en de 'stille' cinematografie}

Interessant genoeg komen al deze vormen van geluid(snotatie) samen in het project van de Futuristische cinema. In I9I6 wordt naar aanleiding van de realisatie van de film viTA FUTU RISTA (Futuristisch leven) het manifest van de Futu- 


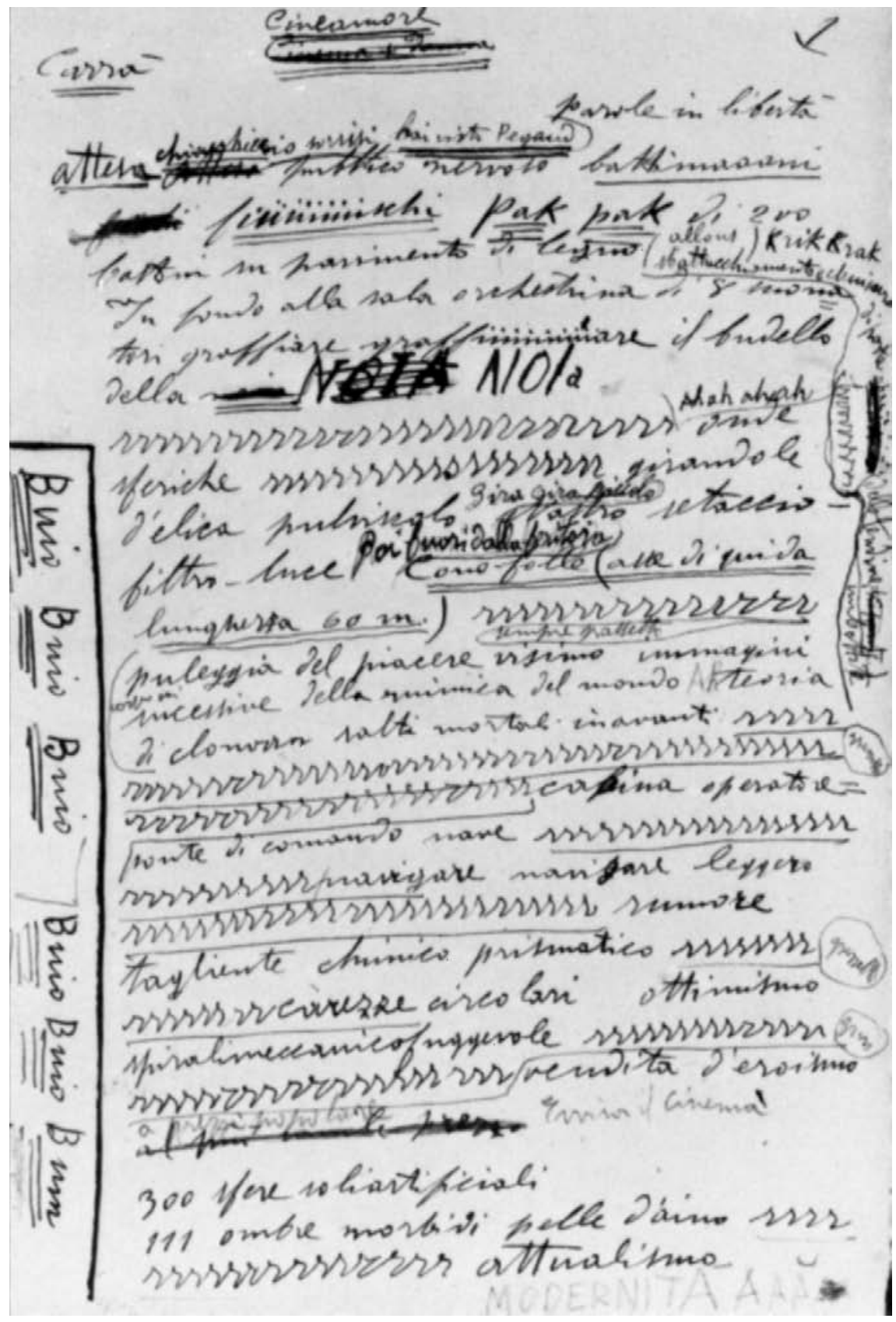

Afb. 10 Carlo Carrà, Cineamore (1914). Bron: P. Hulten,

Futurismo \&

Futurismi, Milano, Bompiani, 1986 , p. 164

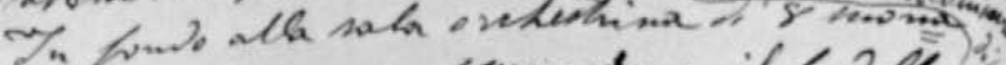

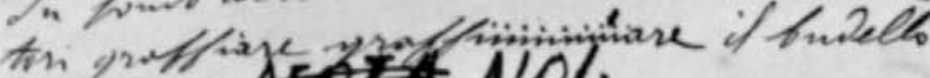

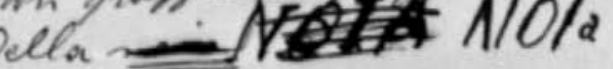

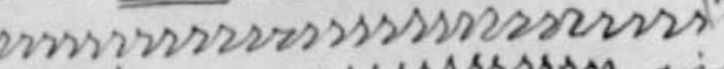

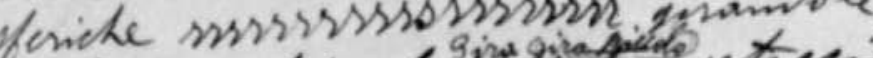

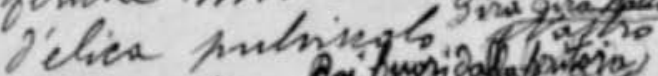

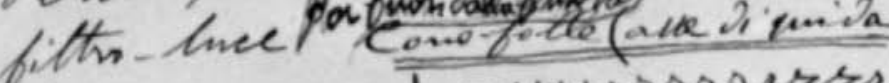

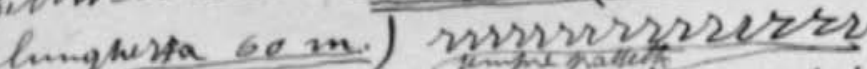

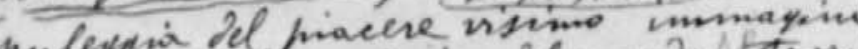
incestive Jella miniea del momo A tersa

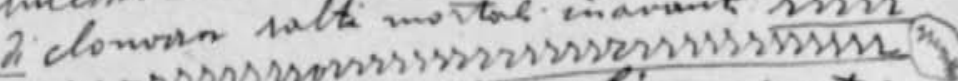

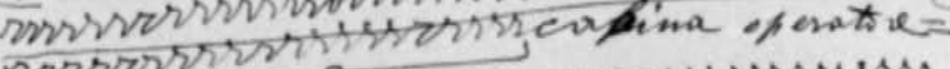

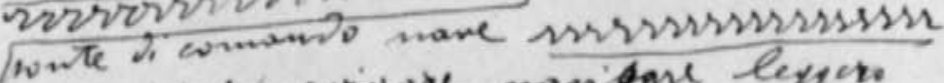
ossssssmavifare manigare leygat

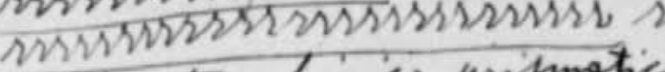
taycerte chime primo

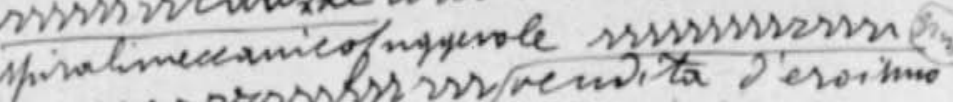
moriersorss 4 min linemal 300 fore whinticial. 111 ombre masbigi tolle. siserseres attuakino

ristische cinematografie gepubliceerd. Zoals in de andere Futuristische kunstdisciplines bestaat er een nauwe band tussen praktijk en theorie: zonder een loutere toepassing of beschrijving van elkaar te zijn, complementeren ze elkaar. Zo is het manifest van de Futuristische cinematografie geen verslag van een tech- 
nisch experiment; integendeel, aan de hand van veertien cinematografische formules legt het de basis voor een nieuwe (avant-garde) cinema. Het manifest sluit af met een wiskundige vergelijking waarin de Futuristische cinematografie wordt gedefinieerd als de som van alle andere Futuristische kunsten, als een Futuristisch Gesamtkunstwerk:

'Schilderkunst + beeldhouwkunst + plastisch dynamisme + woorden-invrijheid + lawaaimachines + bouwkunst + synthetisch theater = Futuristische cinematografie. ${ }^{40}$

Naast Marinetti's paroliberismo worden zowel de picturale techniek van het plastisch dynamisme die Russolo toepast in zijn geluidenschilderij Musica als zijn intonarumori geïntegreerd. Het is echter niet duidelijk hoe deze laatste moeten worden geëxploiteerd: als direct geluid en dus als begeleiding van het stille beeld ofwel als gefilmd geluid en dus geluidloos, door het in beeld brengen van de instrumenten zelf. ${ }^{4 \mathrm{I}}$ Zoals Dominique Noguez opmerkt, is het geluid een lacune in de filmkunst die door de Futuristen tegelijkertijd wordt 'aangevoeld en verdrongen'. ${ }^{42}$ Enerzijds ervaren ze de afwezigheid van geluid als een leegte die moet worden opgevuld door 'dissonanties, akkoorden, symfonieën van gebaren, feiten, kleuren, lijnen, enz.' of door 'lineaire plastische, chromatische, enz. overeenkomsten' van muziek en geluid. Dit zijn de eerder geciteerde proposities nr. 4 en nr. I3 van het manifest van de Futuristische cinematografie die Ginanni-Corradini's chromatische filmonderzoek herformuleren tot Futuristische taal. De Futuristen beogen ook 'gefilmde analogieën' te gebruiken om de stomme dialogen te verlevendigen en om de personages 'begrijpelijk' te maken 'alsof ze zouden praten', ${ }^{43}$ wat eigenlijk neerkomt op het concept van de talkie. Anderzijds blijft het hele project van de Futuristische cinema zeer sterk verbonden aan de picturale oriëntering van de Futuristen en wordt de afwezigheid van geluid niet werkelijk gemist: het volstaat dat de muziek zich vertaalt in chromatische akkoorden en dat de woorden-in-vrijheid ophouden literatuur te zijn om schilderkunst te worden. De Futuristen leggen daarom nadruk 'op het minst verbale karakter van het woord, namelijk zijn typografische zijn'44 en op de mogelijkheid om dankzij het filmische paroliberismo een brug te slaan tussen woord en object. Zo lezen we in het manifest:

'We zullen de woorden-in-vrijheid in beweging stellen: ze zullen de grenzen van de literatuur doorbreken en opmarcheren naar de schilderkunst, de muziek, de lawaaikunst en ze zullen een wonderlijke brug slaan tussen het woord en het reële object. ${ }^{45}$

In de Futuristische cinematografie worden woord en klank herleid tot hun representatieve dimensie. Lawaai wordt 'verstomd' in visuele kleurenakkoorden en filmische analogieën. Hieruit concluderen dat de essentie van het Futurisme 


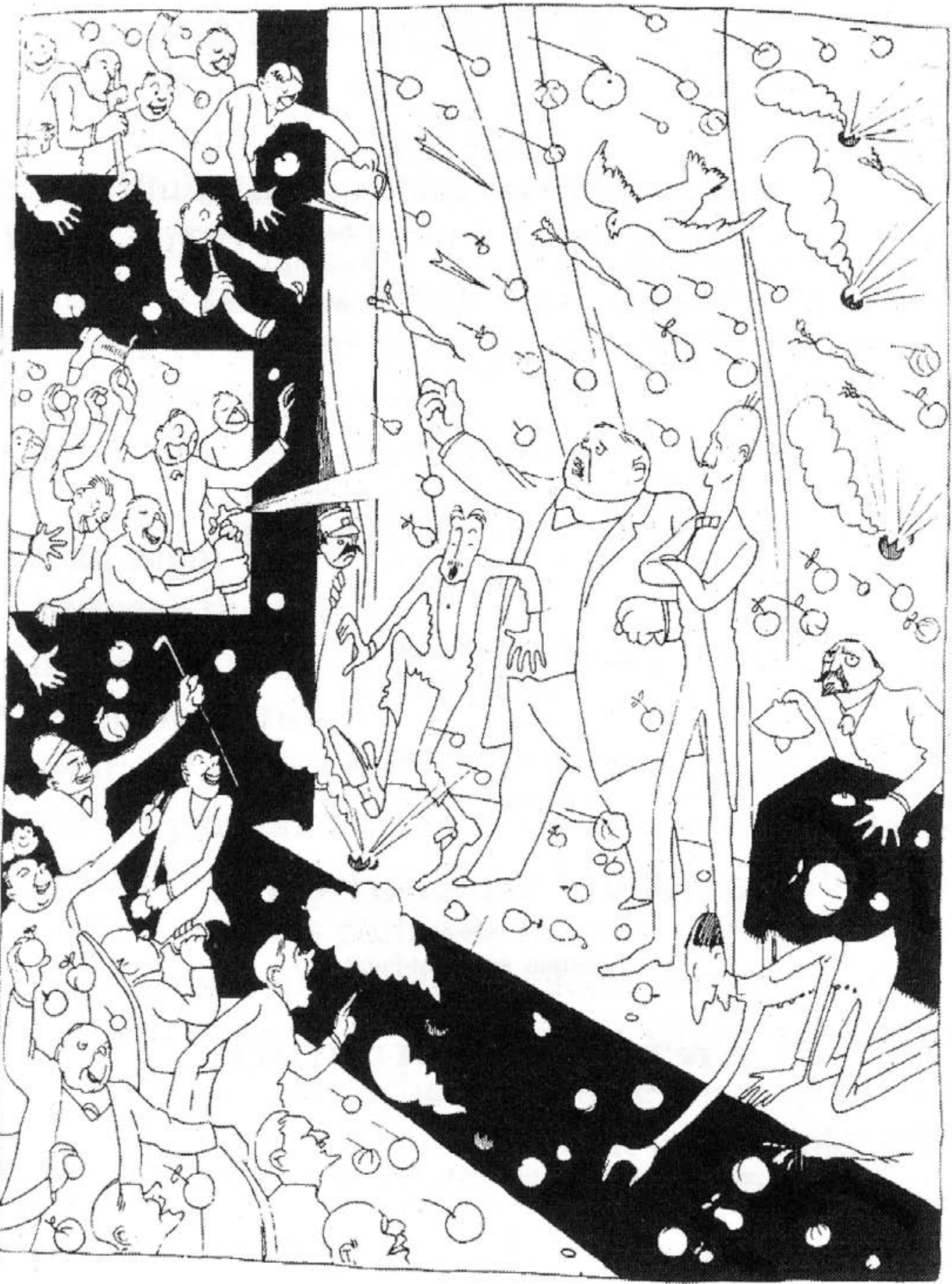

Afb. 11 Karikatuur van een Futuristische avond door Giovanni Manca. Bron: Il Pasquino, nr. 11, 20 maart 1910 
geluidloos lawaai was en dat haar subversieve Gesamtkunstwerk niet anders inhield dan stilte, is wellicht een stap te ver. De stilte van de Futuristische cinematografie had uiteraard ook te maken met de technologische stand van zaken: in I9ı 6 was de talkie simpelweg nog geen feit. Bovendien is de 'stille' film nooit echt geluidloos geweest: in het begin van de twintigste eeuw werd het bewegende beeld meestal live begeleid met commentaar van explicateurs en met sound effects van piano, orkest, grammofoon of intonarumori avant la lettre. ${ }^{46}$ Ook Russolo ging later met zijn lawaaimachines stille avant-garde films begeleiden. Hij bracht verschillende intonarumori samen in een nieuw instrument, het zogenaamde Rumoerharmonium (Rumorarmonio), waarmee hij bijvoorbeeld de 'muzikale illustratie' van LA MARCHE DES MACHINES (I928) van Eugène Deslaw verzorgde. ${ }^{47}$

Een ander belangrijk detail is dat de Futuristische cinematografie rumoerig wilde zijn in haar performance. Zo was de première van viTA FUTU RISTA op 28 januari I9I7, te Firenze, eigenlijk een flop: het publiek dat met de jaren ontvankelijker was geworden voor de Futuristische provocatie, reageerde zonder al te veel kabaal. 'Weinig gefluit, weinig ironisch gelach en geen eetwaren', schreef een journalist's anderendaags in Nuovo Giornale. Maar er kwamen andere voorstellingen die volgens de Futuristische overlevering (en vooral volgens Arnaldo Ginna's getuigenis) beter slaagden: het publiek werd uitgenodigd om actief (en agressief) deel te nemen aan de Futuristische happening $\left(\mathrm{afb} . \mathrm{II}^{48}\right)$, er werd met tomaten en schoenen naar het witte doek gegooid en er ontstonden relletjes. ${ }^{49}$

Het clichématige 'Futurisme = lawaai' heeft dus zeker een grond van waarheid. Maar het Futurisme was niet alleen lawaai. In het manifest van de Futuristische cinematografie wordt de afwezigheid van geluid op geen enkele manier geproblematiseerd. Hoe de stille film lawaaierig kon worden gemaakt, is een vraag die de Futuristen zich in I9I6 niet stelden. En als ze er al 'geluid' aan probeerden toe te voegen, was het niet door akoestische, maar door visuele effecten!

Hetzelfde principe geldt ook voor Russolo's geluidenschilderkunst, GinanniCorradini's kleurenschilderkunst en Marinetti's woorden-in-vrijheid: in al deze verschillende kunstvormen worden klanken gevisualiseerd. In dit artikel heb ik precies willen aantonen dat het akoestische aspect van het Futurisme moeilijk stricto sensu, in termen van geluid kan worden gevat. De verschillende notatiesystemen - picturaal ('vloekende kleuren'), filmisch ('chromatische akkoorden' en 'gefilmde analogieën'), muzikaal ('lawaaikunst'), typografisch ('zang tumb tumb') - bepalen de klanken zo sterk dat het onmogelijk is om een abstractie te maken van hun visuele dimensie: klank wordt beeld.

Hieruit kunnen we twee extreme conclusies trekken. Ofwel was de Futuristische kunst een puur visuele kunst, een kunst zonder (intrinsiek, essentieel) geluid. Ofwel had de Futuristische kunst geen klank nodig om luidruchtig te zijn, want dit was en blijft ze in wezen. Zo blijven haar schilderijen 'oorverdovende en triomfantelijke fanfares', schallen en roepen haar woorden-invrijheid zelfs de eenentwintigste-eeuwse lezer nog toe, in crescendo. 
I. L. Russolo, 'The Art of Noises (extracts) I9I3', in: U. Apollonio (red.), Futurist Manifestos, London I970, p. 74 .

2. Zie bijvoorbeeld M. Berman, All That Is Solid Melts into Air: The Experience of Modernity, New York I988. Dit werk is een 'study in the dialectics of modernization and modernism', zoals Berman het zelf toelicht in de inleiding 'Modernity - Yesterday, Today and Tomorrow' (p. i6). In het voorwoord van de Penguin-editie benadrukt hij hoe zijn benadering 'enables us to see all sorts of artistic, intellectual, religious and political activities as part of one dialectical process, and to develop creative interplay among them. It creates conditions for dialogue among the past, the present and the future. (...) Certainly this is not the only way to interpret modern culture, or culture in general. But it makes sense if we want culture to be a source of nourishment for ongoing life, rather than a cult of the dead.' (p. 5-6).

3. Vooral de karikaturen van André Warnod die de eerste Franse vertaling van het Technische manifest van de Futuristische schilderkunst illustreerden, hebben een dergelijke stereotypering in de hand gewerkt. Deze vertaling verscheen in Comoedia in mei I9ıo, terwijl de eerste Parijse tentoonstelling van de Futuristische schilders pas plaatsvond in februari ı9I2. Hun kunst was dus gekend (en gekarikaturiseerd) alvorens te zijn vertoond.

4. Het clichématige 'Futurisme = lawaai' wordt goed gevat in de montage van S.G. Groenewald op de website: http://www.groenewald.nl/moderne/futurisme/futurisme.htm (I2/09/2000).

5. U. Boccioni, C. Carrà, L. Russolo, G. Balla, G. Severini, 'Futurist Painting: Technical Manifesto I9Io', in: Apollonio, Futurist Manifestos, p. 29.

6. C. Carrà, 'The Painting of Sounds, Noises and Smells I9I3', in: Apollonio, Futurist Manifestos, p. III-II2.

7. Boccioni \& altri, 'Futurist Painting: Technical Manifesto', p. 28.

8. C. Tisdall, A. Bozzolla, Futurism, London I977, p. 57.

9. A.L. Rees, 'Abstract film', in: A History of Experimental Film and Video, London, British Film Institute, I999, p. 28. Zie ook N. Blumenkranz-Onimus, 'Bruno Corradini: Cinéma abstrait, musique chromatique (I9I2)', in: D. Noguez (red.), Cinéma: Théorie, Lectures, Paris I978, p. 267-269; en G. Lista, 'Les trois étapes de la cinématographie futuriste: la ciné-peinture, le théâtre filmé, le cinéma', in: Les futuristes, Paris I988, p. 63-70.

Io. B. Corra, 'Musica cromatica', in: M. Verdone, Cinema eletteratura del futurismo, Roma I968, p. 242-25I.

II. Zie de getuigenis van Arnaldo in G. Bendazzi, Topolino e poi: cinema d'animazione dal 1888 ai nostri giorni, Milano I978, p. 26: 'De fotogrammen van de experimenten uit i9ıo heb ik al jaren niet meer. Heeft iemand anders ze? Misschien zijn ze ergens verloren gegaan? Ofwel vernietigd? [...] We hechtten er geen belang aan... die experimenten, vooral het filmpje naar aanleiding van Segantini, werden uitgevoerd om "chromatische muziek" te verkrijgen.'

I2. Ik bedoel hier niet 'abstract' in de muzikale betekenis (van de 'abstracte muziek' in tegenstelling tot de 'concrete muziek' volgens Pierre Schaeffer, die hieronder aan bod komt), maar in de zin van 'geabstraheerd': muziek die ontdaan is van haar muziek-zijn, van haar klanken en van haar kleuren of chromatiek. Wellicht valt hier, zoals Karin Bijsterveld me heeft gesuggereerd, een vergelijking te maken met Mondriaans Nieuwe Beelding en zijn streven naar een 'abstract-reële’ weergave van de werkelijkheid: een weergave die zich op de werkelijkheid baseert maar deze tegelijkertijd abstraheert. Verder geloofde Mondriaan, net als de broers Ginanni-Corradini, in een exacte overeenkomst tussen de kunsten. Muziek moest dan ook volgens hem een vorm van 'abstract-reële' schilderkunst worden.

I3. 'Voor Prometheus had Skrjabin [...] een vocaliserend eindkoor en doorlopende lichteffecten voorzien; deze laatste moeten door een "tastiere di luce" of lichtklavier verwekt worden. De piano, die in dit werk een aanzienlijke rol vervult, symboliseert er de Mens als microcosmos, ondergedompeld in de macrocosmos van orkest en koor.' (in: A. Corbet, W. Raap (red.), Algemene Muziekencyclopedie, Antwerpen/Amsterdam, I957-1963, vol. 6, p. 348).

I4. Zie G. Fihman, 'De la "Musique chromatique” et des "Rythmes colorés" au mouvement des couleurs', in: Fotogenia, jrg. I, I994, p. 319-323. 
I5. Bendazzi, Topolino e poi, p. 26.

I6. Het eerste Florentijnse Futurisme werd geanimeerd door Giovanni Papini en Ardegno Soffici, die beiden in de redactie van het tijdschrift Lacerba zaten. Toen zij in december I9I4 openlijk Marinetti aanvielen, leidde dit tot een definitieve breuk tussen de Lacerbianen en de Milanese Futuristen. In I9I6 ontstond er te Firenze een nieuwe Futuristische kern, geleid door een groep van jonge vrienden, onder wie Emilio Settimelli, Mario Carli, Remo Chiti en de broers Ginanni-Corradini. Zij lanceerden het nieuwe tijdschrift L'Italia Futurista en zorgden voor een kortstondige heropleving van het Futurisme in Firenze: het zogenaamde tweede Florentijnse Futurisme.

I7. Deze definitieve versie is opgenomen in: Verdone, Cinema e letteratura del futurismo, p. I74-I94.

I8. Idem, p. I83, p. I78.

19. Idem, p. I76.

20. Het Akkoord is een 'samenraapsel van gelijktijdige klanken', het Motief een 'samenraapsel van opeenvolgende klanken'. Het Beeld-Akkoord wordt omgeschreven als 'het gelijktijdig presenteren van een idee en een akkoord dat die idee uitdrukt', terwijl het Beeld-Motief wordt toegelicht als 'actie (ten tonele gevoerd of op andere wijze gerepresenteerd), plus motief, of motieven die deze actie uitdrukken' (idem, p. I79). Opvallend is het verschil in betekenis dat aan 'imagine' wordt toegekend in combinatie met respectievelijk 'accordo' en 'motivo': in het eerste geval wordt 'imagine' gelijkgesteld aan een mentaal beeld, terwijl het in het tweede geval gaat om een concreet beeld, een in-beeld-brenging (mise-en-image) van actie. Met andere woorden, het simultane ('accordo') blijft abstract, het successieve ('motief') concretiseert zich.

2I. F.T. Marinetti, B. Corra, E. Settimelli, A. Ginna, G. Balla, R. Chiti, 'The Futurist Cinema', in: Futurist Manifestos, p. 218.

22. W. Pee, 'Chromatiek', in: Algemene Muziekencyclopedie, vol. 2, p. I05 ev.

23. J. Waterhouse, 'Futurist music in historical perspective', in: Futurismo 1909-1919. Exhibition of Italian Futurism, Newcastle I972, p. 94.

24. Algemene Muziekencyclopedie, vol. 4, p. 568.

25. Waterhouse, 'Futurist music in historical perspective', p. 94-96. Zie Russolo, 'The Art of Noises', p. 86: 'Although it is characteristic of noise to recall us brutally to real life, the art of noise must not limit itself to imitative reproduction. It will achieve its most emotive power in the acoustic enjoyment, in its own right, that the artist's inspiration will extract from combined noises.'

26. Zoals Karin Bijsterveld in 'A Servile Imitation: Disputes about Machines in Music, I9IoI930' (in: H.-J. Braun (ed.), Music and Technology in the Twentieth Century, Baltimore and London 2002, p. I2I-I35) aantoont, werden de Futuristen - ondanks deze duidelijke stellingname tegen klankimitatie - door tijdgenoten juist beschuldigd van 'slaafse imitatie van het dagelijks leven'. Bijsterveld bespreekt uitvoerig de kritiek van componist George Antheil en van schilder Piet Mondriaan.

27. K. Goeyvaerts, 'Concrete Muziek', in: A. Corbet, W. Raap (red.), Algemene Muziekencyclopedie, vol. 2, p. I58. Zie ook P. Schaeffer, Traité des objets musicaux, Paris I966, p. I7: 'La musique concrète prétendait composer des œuvres avec des sons de toutes provenances - notamment ceux qu'on appelle bruits - judicieusement choisis, et assemblés ensuite grâce aux techniques électroacoustiques du montage et du mélange des enregistrements.' In zijn dagboekfragmenten in A la recherche d'une musique concrète (Paris I952, p. 98) brengt Schaeffer, naar aanleiding van een interview met de R.A.I., het werk van Russolo ter sprake: 'C'est Russolo qui avait inventé l'intonarumori. Qu'était-ce au juste cet instrument? Une sorte de piano préparé? Ou quelque chose d'analogue à mon premier orgue à bruits?' Vervolgens, in La musique concrète (Paris I967, p. 6), erkent Schaeffer naast Varèse en Cage de Futuristen als zijn (weliswaar 'naïeve') voorgangers; Russolo's L'Art des bruits neemt hij op in zijn 'bibliographie sommaire'.

28. F.T. Marinetti, 'Geometric and Mechanical Splendour and the Numerical Sensibility I9I4', in: Futurist Manifestos, p. 157.

29. In deze vorm van declamatie wordt het hele menselijke lichaam betrokken met de bedoeling het te verontmenselijken: de stem wordt metaalachtig, de gesticulatie geometrisch en de handen bedienen allerlei lawaaiproducerende instrumenten. 
30. Zie A. de Campos, D. Pignatari, H. de Campos, 'Plano-Pilõto Para Poesia Concreta / Pilot Plan for Concrete Poetry’, in: M.E. Solt (red.), Concrete Poetry: A World View, Bloomington I97I, p. 72.

3I. M. Webster, Reading Visual Poetry after Futurism. Marinetti, Apollinaire, Schwitters, Cummings, New York, I995, p. 28.

32. J. White, Literary Futurism, Oxford I990, p. I2.

33. Webster, Reading Visual Poetry after Futurism, p. I3-4I.

34. Marinetti, 'Geometric and Mechanical Splendour', p. I57.

35. F. de Saussure, Cours de linguistique générale, Paris I922 (2e editie), p. Ioo-Io2.

36. Cours de linguistique générale, geredigeerd door Charles Bally en Albert Sechehaye, is gebaseerd op de lessen die De Saussure gaf in I907-I9ıI.

37. Deze problematiek is reeds door verscheidene semiotici en specialisten van het Futurisme besproken. Zo heeft Fausto Curi het poëtische systeem van Marinetti definiëerd als 'stylistiek van de materie', omdat voor Marinetti 'het teken slechts een reflectie van de referent vormt, het substantief is het object, het neemt zijn identiteit aan' ('Una stilistica della materia: F.T. Marinetti e le "parole in libertà”', in: J.-C. Marcadé (red.), Présence de F.T. Marinetti, Lausanne, I982, p. 37). Clara Orban, die zich op de studie van Curi baseert, merkt op: 'The signifiers now become signifieds, objects that can exist as images. [...] Marinetti literalizes the iconic potential of the written word, creating images where there were words.' (C. Orban, The Culture of Fragments: Words and Images in Futurism and Surrealism, Amsterdam/Atlanta, I997, p. 47).

38. Marinetti, 'Geometric and Mechanical Splendour', p. 158.

39. Y. Tsivian, Early Cinema in Russia and its Cultural Reception, London/New York I994, p. II9.

40. Marinetti \& altri, 'The Futurist Cinema', p. 2I8.

4I. Geluid werd vaak op die manier in stille film gevisualiseerd. Zo zien we in LA DIXIEME SYMPHONIE (I9I8) van Abel Gance een componist zijn nieuwe symfonie op een piano vertolken, terwijl in TH Е MAN wiтн TH Е M Ovi CAM E RA (I929) van Dziga Vertov een visueel orkest de film in de film begeleidt.

42. D. Noguez, 'Du futurisme à l' “underground”', in: Noguez, Cinéma: Théorie, Lectures, p. 289.

43. Marinetti \& altri, 'The Futurist Cinema', p. 2 I7.

44. Noguez, 'Du futurisme à l' “underground”', p. 288.

45. Marinetti \& altri, 'The Futurist Cinema', p. 208.

46. In Scenario (nr. I6, I937) beschrijft Mario Corsi een cinematografisch evenement dat in I9OI, te Orvieto, plaatsvond om de installatie van het elektrisch licht in te huldigen: op de markt projecteerde men het filmpje L'ARRIVÉE D'UN TRAIN EN GARE van de gebroeders Lumière dat 'voor de gelegenheid gesynchroniseerd' was. Corsi specifcieert: 'Een geluidendirigent [direttore dei rumori], voorzien van zijn bizarre instrumenten, had zich in een tent naast het scherm geplaatst.'

47. In I962 schrijft Eugène Deslaw in een brief aan Mario Verdone: 'Zoals u weet was Russolo mijn medewerker voor LA MARCH E D ES MACH I N Es. Hij maakte voor mijn film de muzikale illustratie op zijn bruiteur Rum Garmonium (dat wil zeggen Russolo en Marinetti Garmonium).' (in: Verdone, Cinema e letteratura del futurismo, p. II8). Deslaw zou in I930 ook een reportage over Russolo en zijn Rumorarmonio hebben gedraaid. Deze reportage is echter verloren gegaan. LA MARCHE DES MACHINES is daarentegen wel bewaard gebleven, maar helaas zonder Russolo's 'klankband' (die niet vastlag in een klankspoor op de film, maar live werd opgevoerd). De marcherende machines uit de titel zijn geen lawaaimachines, maar poppen.

48. Elf illustraties omdat II Marinetti's magisch, fetisj getal was.

49. A. Ginna, 'Note sul film d'avanguardia vita futu rista', in: Bianco e Nero, mei-juni I965, p. I57; en 'Altre note su vitA FUTU RisTA', in: Verdone, Cinema e letteratura del futurismo, p. Io8. 